\title{
The Central-European Economic Effects of the World War I
}

\section{Ferenc SZÁVAI}

\author{
Nemzetközi Gazdasági Kapcsolatok Tanszék \\ Módszertani Intézet \\ Gazdaságtudomány, Kaposvári Egyetem \\ Department of International Economic Relations \\ Institute of Methodology \\ Faculty of Economic Science of the Kaposvár University \\ Guba Sándor u. 40, 7400 Kaposvár, Hungary \\ szavai.ferenc@ke.hu
}

\section{Introduction}

On 28 June 1914, a war started which was conducted on a scale that had been hitherto unknown. Contemporaries considered it a dual world war because on the one hand, it involved the whole world, and on the other hand, it was fought for global influence.

Central European countries could rely only on their domestic resources. The cost of World War I was as much as 180-230 billion dollars (1914 purchasing power); even indirect costs were over 150 billion dollars. ${ }^{1}$

In addition to economic depletion another phenomenon occurred, notably, international economic disintegration. The complicated and fragile system of international labour division, which had been designed before World War I, brought an era of welfare and prosperity for the people of Europe. However, the favourable economic conditions collapsed immediately after the outbreak of war, and resulted in such destruction the like of which had never been experienced before. The restructuring of the global economy was particularly difficult, and there were great losses and considerable damages. The event was characterised by material destruction: the destruction of housing, industrial plants and equipment, mines, livestock and agricultural machinery, and traffic and communication equipment; as well as the losses in Eastern European war operations. Furthermore, merchant shipping was severely damaged by the unrestricted submarine warfare. However, it was the economic damages that were more severe: the deterioration, and dissolution and confusion of economic relations. The breakup of previous commercial relations was possibly the most serious; in addition, the war destroyed the equilibrium of global agriculture too. Besides the loss of revenues from foreign investments, inflation weakened most Central European economies. Let us see how World War I affected Central Europe and what disintegrative effects it had after the Peace Treaties, following the war.

1 Stephen BROADBERRY - Mark HARRISON (eds.), The Economics of World War I, Cambridge 2005, 24. 


\section{Economic Depletion Depletion of the Labour Force - Military Recruitment}

According to the reports of General Kerchnawe, the number of those in the AustroHungarian Monarchy recruited by the end of August 1918 was 7,250,000 in total, and this number was supposed to reach $7,500,000$ by the end of October. This figure equalled to approximately $13,4 \%$ of the total population of the Austro-Hungarian Monarchy, at the same time it accounted for $27 \%$ of the male population and $73 \%$ of the military-age males (from 18 to 50 years of age).

17,54 inhabitants out of 100 were recruited from Hungary, 16,09 from Austria and 12,04 from Bosnia-Herzegovina.

Human losses are of primary importance when describing the depletion of human resources during World War I. Altogether 905,299 people were killed in the war; 495,169 were Austrian, 380,774 Hungarian and 29,356 Bosnian. So $54,7 \%$ of the casualties were Austrian, 42,05\% Hungarian and 3,24\% Bosnian. In terms of per 1000 inhabitants this means 17,73 Austrians, 18,48 Hungarians and 16,46 Bosnians, whereas in the monarchy, as a whole, 17,99 out of each 1000 inhabitants were killed. According to the records from the Ministry of War of 6 November 1918, the number of the injured was 1,838,450, out of which 1,029,716 were Austrian, 743,359 Hungarian and 65,375 Bosnian inhabitants. By percentage, $56,01 \%$ of the injured were Austrian, 40,43\% Hungarian and 3,56\% Bosnian. In terms of per 1000 inhabitants this means 36,87 Austrian, 36,07 Hungarian and 36,65 Bosnian injured inhabitants, whereas the average number of the injured in the monarchy as a whole was 36,53 out of each 1000. The same figures from the records from the Ministry of War of 6 November 1918 also show that the number of prisoners of war was 1,479,289, out of which 835,384 were Austrian, 614,808 Hungarian and 29,097 Bosnian. Thus, 54,88\% of the prisoners were Austrian, 42,26\% Hungarian and 2,86\% Bosnian. In terms of per 1000 inhabitants this means 29,90 Austrian, 29,83 Hungarian and 16,31 Bosnian prisoners of war. Finally, according to the records of 6 November 1918, the total loss (dead, injured, missing and prisoners of war) can be estimated to be 5,060,521 people; 54,88\% of them were Austrian, 42,26\% Hungarian and 2,86\% Bosnian. In terms of per 1000 inhabitants, there were 99,44 casualties in Austria, 103,74 in Hungary and 81,05 in Bosnia-Herzegovina. ${ }^{2}$

The exceptionally severe human loss together with the resulting labour shortage caused serious economic difficulties in industry as well as in agriculture. The Peacetime Footing of the joint Imperial and Royal Army was 450,000, in 1916 and 1917 it increased to 4,900,000 and $5,100,000$ respectively. Hungarian soldiers accounted for $46,6 \%$ of the joint army, which meant that approximately 2,500,000 soldiers were recruited from Hungary; this constituted a third of the working age male population, who dropped out of industrial or agricultural production.

The increasing number of recruited working age men meant a seriously expanding loss of labour force for the industry. In some areas serious labour force shortages occurred very early on, and the shortages became a general phenomenon which later spread to all areas.

2 Gustav GRATZ - Richard SCHÜLLER, Der wirtschaftliche Zusammenbruch Österreich-Ungarns. Die Tragödie der Erschöpfung, Wien 1930, 149-164. 
The number of adult male workers employed in the Hungarian industry decreased from 287,000 to 142,000 , almost by half. This meant that workers with considerable professional knowledge dropped out from economic production. 60,000 so-called war labourers were used as substitutes for the recruited workers; they were partly unfit for military service and retrained fresh recruits. Later, approximately 30,000 prisoners of war were sent into the factories. In addition, large numbers of women and girls who were supposed to provide for their families were employed in the industrial plants. The percentage of the female workforce in 1913 was $22,8 \%$, which grew to $28,2 \%$ by 1917 . Yet by training this contingent workforce the total proportion of factory workers decreased to 12,7\% by 1917.

Already as early as in 1915, due to military needs, the livestock of horses in agriculture was 30-40\% smaller than before the war. Livestock decreased substantially and it was not possible to supply the necessary numbers of beasts of burden in spite of the fact that cattle were being used for this purpose in growing numbers. Moreover, there were fewer machines available for agricultural use due to petrol shortages, and the lack of maintenance and available machine parts. As a result increasing areas of arable land were not farmed, farm work was often incomplete, and yields fell. ${ }^{3}$

\section{Depletion of Capital - Financing the War}

It is evident that the war depleted the capital of all participating countries. This is especially true for the ones which lost the war, and which collapsed under the burden. Still, the collapse did not become visible until a few years after the Peace Treaties; this meant that the financial depletion of the Austro-Hungarian Monarchy at the end of the war took some time to reach its peak. Consequently, once both countries reached their peaks of financial depletion it affected their economies for many years to come.

Different calculations have been made in connection to the extent of direct military expenses. It is simply a coincidence that Teleszky and Winkler have estimated an amount equivalent to the Hungarian bottom line. According to the previously referred to expenses, the two states of the monarchy transferred 68,588 million crowns as 'recruitment credit' between 1 July 1914, and 31 October 1918, which in reality meant 68,295 million crowns. By contrast, the Austrian finance ministry's calculations with the title "The balance of the joint public finance and temporary current account indicators between 1 July 1914 and 31 October 1918" showed that total military expenses reached 70,827 million crowns.

The amounts of the military expenses of Austria and Hungary between July 1914 and June 1918 can be calculated as Table 1 shows (in million crowns):

3 Iván T. BEREND - György RÁNKI, Ungarns wirtschaftliche Entwicklung 1849-1919, in: Die Habsburgermonarchie 1848-1918, Adam WANDRUSZKA - Peter URBANITSCH (eds.), Band I. Die wirtschaftliche Entwicklung, Alois BRUSATTI (ed.), Wien 1973, 522-523. 
Table 1

\begin{tabular}{|l|l|l|}
\hline & Austria & Hungary \\
\hline quota contribution to military expenses & 39000 & 23000 \\
\hline the wounded & 730 & 35 \\
\hline military refugees & 1900 & 90 \\
\hline nursing contribution & 7000 & 3400 \\
\hline ,re-instalment' of military areas & 700 & 90 \\
\hline military debt service & 3500 & 1500 \\
\hline & 52830 & 28025 \\
\hline
\end{tabular}

Winkler's taxative calculations of the particular military expenses - seen as part of the total military costs, result in lower numbers than Teleszky's indirect calculations. Table 2 shows the difference between the figures (in billion crowns): ${ }^{4}$

\section{Table 2}

\begin{tabular}{|l|c|c|c|}
\hline & Austria & Hungary & Total \\
\hline Direct calculation (Winkler) & 53 & 28 & 81 \\
\hline Indirect calculation (Teleszky) & 57 & 33 & 90 \\
\hline
\end{tabular}

The expenses of the war were partly covered by reliance on the central bank. On the basis of a table published by Sándor Popovics the Austro-Hungarian Bank used an amount of 39,392,003,000 crowns between 14 August 1914 and 31 October 1918; 25,053,313,908 crowns for Austria and 14,338,689,092 crowns for Hungary. A closer examination of this table reveals two significant phenomena, which were emphasised by Popovics and Teleszky too. One of them is the increasing financial reliance on the Austro-Hungarian Bank. The other phenomenon, which is important in evaluating the depletion, is the fact that Austria's financial needs increased at a faster pace than Hungary's. In accordance with the quota proportion Austria borrowed 20,034 million coronas from the Austro-Hungarian Bank between 15 July 1915 and October 1918, in return for national debt liability; the equivalent amount for Hungary was 11,466 million crowns. ${ }^{5}$

After November 1914 both countries made efforts to cover part of the military expenses by the issue of war bonds. The Austrian government issued war bonds eight times. In total, war bonds worth $35,129,324,600$ crowns in nominal value were issued; the actual revenue was $32,955,576,990$ crowns, which equalled to $93,8 \%$ of the average rate. Hungary planned 17 issues of which subscription was public for 13 while 4 were issued for subscription at the monarchy's banks. The revenue amounted to $18,851,835,850$ crowns in nominal value (in effect $17,955,885,538$ crowns); their average exchange rate was $95,4 \%$.

The proportion of the revenues to be gained from war loans issued by the two countries was $64,7: 35,3$. In contrast to the quota proportion agreed upon between Austria and Hungary, intended to cover the joint expenses $(63,6: 36,4)$, Austria's amount was half a billion crowns higher, while Hungary's was half a billion crowns lower. ${ }^{6}$

4 GRATZ - SCHÜLLER, 165-170.

5 Ibidem, 171-175.

6 Ibidem, 176-178. 
The figures show that in the first year of the war the amount of money in circulation doubled and the greatest increase occurred in the first half of the year, more precisely in the first four months of the war until November 1914. Afterwards, the growth was mostly stable and less considerable.

Table 3 shows how the Austro-Hungarian crown was valued in Zurich, the most important market of the monarchy's money (based on 100 crowns).

\section{Table 3}

\begin{tabular}{|l|c|}
\hline by parity & 105 francs \\
\hline August 1914 (average) & 97,50 francs \\
\hline June 1915 (average) & 80,19 francs \\
\hline June 1916 (average) & 66,75 francs \\
\hline June 1917 (average) & 44,02 francs \\
\hline June 1918 (average) & 43,01 francs \\
\hline October 1918 (average) & 43,74 francs \\
\hline
\end{tabular}

Supposing that the price increase took place at an even pace all through the period, it is possible to contrast the index numbers of the price growth and those of the banknote growth, as shown in Table 4:7

\section{Table 4}

\begin{tabular}{|l|c|c|}
\hline & Value & Banknotes in circulation \\
\hline July 1914 & 100 & 100 \\
\hline June 1915 & 213 & 208 \\
\hline June 1916 & 319,4 & 281 \\
\hline June 1917 & 394,8 & 382 \\
\hline June 1918 & 562,7 & 741 \\
\hline October 1918 & 573,3 & 977 \\
\hline
\end{tabular}

Due to military needs and as a result of direct state investments there was an increase in demand for other industrial products, as well. During the war the annual war material delivery made up 1,7 billion crowns, which equalled to 1,15 billion crowns by calculation with the pre-war index. This accounted for approximately 33\% of the 1913 annual industrial production. Considering the fact that industrial production decreased, especially in the second half of the war, war material production reached or even exceeded $50 \%$ in some years.

Steel and metal production grew substantially during World War l; there were considerable efforts made in order to develop domestic ore production and processing. In addition to copper, manganese and zinc extraction, Hungary started bauxite mining. Within the machine manufacturing industry the capacity of arms manufacturing increased substantially; aircraft manufacturing together with prime mover manufacturing developed significantly and almost all machine factories of the country were producing material used in war. Finally, there was a production growth in the chemical industry as well; this branch was involved 
in the manufacturing and development of explosives and other related products (chlorine, nitrogen, methanol industry). The number of workers in these branches generally increased by $30-40 \%$ while the number decreased by $12 \%$ in the industry as a whole. ${ }^{8}$

According to certain estimations the four-year war cost the Hungarian state 32 billion crowns, which was equivalent to 43,3 of the public wealth. The four-year war soaked up the national revenues of two and a half years of peace. This means - considering the decreased industrial and agricultural production during the war, that at least three thirds of the national income produced during the war was eaten up by pointless killing and destruction. ${ }^{9}$

The state interfered and regulated industrial production and restricted it for the sake of army needs and the public service. Such a regulation was, for example, the decree regulating the circulation of mineral oil products at the end of 1915, which authorised ministries to obligate suitable companies to produce particular goods of prescribed quality and quantity if public needs were in danger.

In order to ensure petrol and other crude oil product supplies, it was forbidden to use unprocessed mineral oil for heating, engines or oil gas production.

Waste materials were a significant factor even in peacetime; their significance increased further during the war. Thus, a scrap-iron commission and later a scrap cast iron commission were established to eliminate the price hikes triggered by the competition among iron and steel companies for raw material. A textile waste commission was set up to ensure raw materials for the textile and paper industry while a paper commission was established to ensure raw material for the paper mills of the country.

The state took measures to introduce substitute materials. The first decrees of this kind were related to mixing flour with flour substitutes. Then there were several metal exchange measures, which meant that almost all metal objects in households and in the industry, as well as their parts were substituted with iron, zinc or any other suitable substitutes.

One of the most important war materials, gun-cotton, was manufactured from substitute raw materials too; prepared cellulose was used instead of cotton. Textile was used instead of leather in gas masks, and a lot of substitute materials were introduced in the production of war materials in place of metal, leather or textile parts. Even coins were minted with substitute materials, as nickel was necessary for other purposes - so coins of an alloy of copper, zinc, and nickel or iron were introduced.

Several decrees ordered the reduction in the number of produced goods and in specific types allowed to be manufactured uniformly and exclusively; these measures were primarily adopted in order to save raw materials and to prevent forgeries.

The sale of certain goods was only allowed under certain licences, or according to a certain quality. For example, pesticides against mildew only licensed by the ministry of agriculture were allowed to be sold and used.

There were severe punishments in the law passed in 1916 against the raising of prices. In addition, authority licence was required for the sale of foods and necessaries. ${ }^{10}$

As a result of the increasing and swift inflation the economic collapse peaked during

8 BEREND - RÁNKI, 521.

9 Ibidem, 526-527.

10 József Báró SZTERÉNYI - Jenő LADÁNYI, A magyar ipar a világháborúban, Budapest 1934, $108-119$. 
the war. By autumn 1918 it was clear to most economists that the monarchy was facing imminent economic bankruptcy and would not be able to survive another winter of war. ${ }^{11}$

\section{The Features of Economic Disintegration}

The collapse of the Austro-Hungarian Monarchy also meant the collapse of the economic unity of Central Europe. All this was brought about by the Peace Treaties following World War I as well as by the New Nation States' concepts and ambitions of economic policy by which they committed themselves to economic seclusion instead of cooperation. This era became the stage for economic disintegration associated with hyperinflation and a number of new economic difficulties. Several new economic factors emerged by the beginning of the 1920s; 6-7,000 kilometres of new custom borders, 7 new independent custom areas, 38 economic units in the whole of Europe replacing the former 26, and 27 currencies instead of the former 12. According to the economic policy of disintegration, the elite of the New Nation States believed that economic underdevelopment in their countries had resulted from the lack of national independence and self-determination, and from the conditions of the involuntary empire. Consequently, they tended to rely on economic nationalism, which meant protectionist customs policies and import restrictions. Foreign capital (mainly belonging to the formerly ruling nation) was confiscated. The most important economic difficulties of the new economies included indebtedness, inflation, capital shortage, raw material shortages due to the new customs borders, and sales difficulties.

In addition to the general tendencies, some concrete cases are highlighted below, which surfaced due to the collapse of the Central European economic unity and had to be solved:

1. Legal protection of the Hungarian land properties in regions allocated to neighbouring countries in the Treaty of Trianon; the Romanian-Hungarian, Hungarian-Czech, and Yugoslavian-Hungarian optative cases and their solutions; the activities of the legal protection office.

2. Pensions and the operation by Foundations; the Habsburg family members' citizenship application.

3. Accounts in old crowns.

\section{The Romanian-Hungarian, Hungarian-Czech and South Slavic- Hungarian Property Lawsuits}

The Hungarian owners of the expropriated properties turned to the Hungarian government but the negotiations between the two states failed to succeed. As a consequence, the Hungarian government went to the Council of Ambassadors, which declared that the issue was within the authority of the Council of the League of Nations. Accordingly, the Hungarian government turned to the Council, based on the Uniformity Act 11.2. The Council appointed the Japanese ambassador, Mineichiro Adachi, to press for an agreement but the negotiations of May 1923 failed, however, Count Csáky, the Hungarian representative, did

11 BEREND - RÁNKI, 527. 
sign the last five lines of the Resolution Proposal of 29 May. The Council approved Adachi's Resolution Proposal on 5 July 1923.

Simultaneously with the negotiations, Hungarian landowners whose rights had been violated filed a lawsuit at a joint Romanian-Hungarian court against the Romanian State. The tribunal declared itself as a competent authority in its court ruling of 10 January 1927, as a result the Romanian government called its representative back from the joint tribunal and turned to the Council of the League of Nations. ${ }^{12}$

The Romanian government's argumentation with respect to the authority issue failed. Such authority should have been declared in accordance with article $250 .{ }^{13}$ The rulings of the Romanian agrarian law and the appallingly little restitution did not comply with the general principles of International Law. Thus, they did not comply with articles 63 and 250 of the Trianon Treaty either, which were meant to protect the rights of the Hungarian citizens. ${ }^{14}$

On 14 August 1923 István Bethlen was informed by the ministry of justice, in a confidential letter, about the cases that were being prepared by their Legal Protection Office to be filed to the joint Romanian-Hungarian tribunal before the expiry of the submission deadline at the end of the year. These cases were of Romanian and Czechoslovakian relevance as the Hungarian-South Slavic (Yugoslavian) tribunal was established only later. In this report there were 64 cases related to immovable properties and 59 cases related to movable property in reference to Romania. In reference to Czechoslovakia there were 3 immovable property cases and 18 cases related to movable property. They seemed to be legally defensible. The Office was working on further 806 cases with reference to Romania and one with reference to Czechoslovakia, but the data and evidence were insufficient. In addition, the Office examined further 271 claims for movable properties with reference to Romania and 282 claims with reference to Czechoslovakia, but they were not found suitable for an arbitration hearing. ${ }^{15}$

The National Association of Hungarian Land Credit Institutions addressed a letter to Dr. Tibor Pataky, the head of the ministry department and highlighted two interesting points of the issue. Most importantly, they asked Pataky to warn Bethlen to submit his documents so that they were available as soon as possible to be able to be counted in the above proceeding. The Association dealt with cases in all the three territories allocated to the neighbouring countries, but the establishment of the South Slavic tribunal was still in the preparatory phase. The document shows that the Romanian agrarian reform was much more ,brutal' than the Czech one. The primary difficulties are also shown in the solution of the issue; they are on the one hand the Geneva Convention course of proceedings, and on the other hand financial difficulties. ${ }^{16}$

12 See: Ernst MARBURG, Der rumänisch-ungarische Optantenstreit vor dem Gemischten Schiedsgericht und dem Völkerbund. Zugleich ein Beitrag zur Lehre von der Enteignung im Völkerrecht, in: Frankfurter Abhandlungen zum Kriegsverhütungsrecht. Heft 8, F. GIESE - K. STRUPP (eds.), Leipzig, 1928.

13 Corpus Juris Hungarici. Budapest 1922, Acts from 1921, 294-295.

14 István SZÁSZY, Az államok közötti utódlás elmélete, Budapest 1928, 572-587.

15 Magyar Nemzeti Levéltár Országos Levéltára (The State Archives of the Hungarian National Archives; hereinafter referred only as $\mathrm{MNL}-\mathrm{OL}$ ) - A miniszterlnökség iratai (Prime Minister documents (hereinafter referred only ME) - Kisebbségügyi hivatal (Department of Minorities, hereinafter referred only KH) 149, article 249. 79 file 1/1923.

16 lbidem, Folio 21. 
In addition to the above cases, there are a number of claims of several thousand acres among the lawsuits. Romania appealed against the favourable decision in Paris, thus it questioned the ruling of the Parisian joint tribunal. ${ }^{17}$

On 30 January 1930 Dr. István Szekeres sent extensive documentation to the Prime Minister István Bethlen in relation to Count Géza Edmund Zichy's entailment in Divény, emphasising identicalness with the optative lawsuits. This was an estate of 38,000 acres that was expropriated by a small part of the family at the expense of the Hungarian citizenship family members. The majority of the estate was within Czechoslovakian borders and was dissolved as entailed property following Act 179, which came into force on 14 November 1924. Dr Géza Edmund Zichy filed a lawsuit against this and requested for 1/31 of the property to be registered at the land registry. In his letter to Kálmán Darányi, state secretary, Lajos Walkó explained that the Czech did not use the documentation of the lawsuit against the Hungarians on 18 December 1929 and they did not influence the results of the proceedings. ${ }^{18}$

On 25 July 1926 the South Slavic envoy asked for an extension of the deadline for the optants to leave the properties, from 1 April 1926 for three more years to 26 July $1929 .{ }^{19}$

Following the session on 4 April 1930 the foreign minister in agreement with the prime minister made a proposal to the Yugoslavian government to extend the optants' deadline for leaving the properties until 1 November 1930. In accordance with the Treaty of Trianon they would have been obligated to move their seats to the state where they opted for citizenship within 12 months. The Hungarian Ministry of Defence had serious qualms in connection with the extension. ${ }^{20}$ At a session held at the prime minister's on 28 October 1930 it was declared that Hungarian optants were expected to be "moved" over the border before 1 November 1930. According to the Belgrade envoy's notification 85 family heads and 172 family members were provided for, while 35 family heads and 89 family members were not. The latter needed help. The most urgent problem was housing. The Hungarian party promised concrete measures, notably that the office of the prime minister would take measures to solve the problem of housing for those optants who were not provided for. The Ministry of Welfare started a food programme. The ministries of Commerce and Welfare agreed on the transport costs of the optants moving in. ${ }^{21}$

The Hungarian-Romanian dialogue did not belong amongst the problem-free negotiations with the successor states. The negotiations between the two parties on pensions, funds, foundations, historical archives and public records lasted throughout 17 March to 13 April 1927. Double taxation was one of the most significant issues of the negotiations and further regulations were necessary in connection with the crossing of borders by regional railways. ${ }^{22}$

In a meeting held in the foreign ministry, in connection with negotiations on successor

$17 \mathrm{MNL}-\mathrm{OL}, \mathrm{K} 28, \mathrm{ME}, \mathrm{KH}, 28$. 149. article 249. 46/1927.

18 Ibidem, file 5145/1930.

19 MNL-OL, K 28, ME, KH, file 28 6236/1926.

20 Ibidem, file 5442/1930.

21 Ibidem, folio 40-59.

22 MNL-OL, K 28, ME, KH, 28. 7. article 29, file 0193/1927. 
states, the Romanian participants proposed that a meeting should be convened on 15 August 1926 with the participation of all successor states to deal with the following issues:

- state pensions,

- the case of Hungarian funds and foundations,

- dividing records,

- $\quad$ administrative debts.

In the written answer to this proposal the Hungarian party argued that with regard to the Czech stand there was no point in negotiations on pensions. According to the Hungarian party, the issue of the Gozsdu foundation had to be negotiated before December. ${ }^{23}$

József Szterényi was appointed to phrase the Hungarian standpoint on the optant issue opposite the Romanian standpoint for the ministry session of 15 October 1928.24

Several solutions and manners of payment were worked out; one of them related to redemption. ${ }^{25}$

Several charges were laid against the Hungarian government in connection with the fact that István Bethlen was personally concerned with the resolution of the optant case. Szterényi's counter-argument was that Bethlen placed the country's political interests before his own personal financial interests. ${ }^{26}$

The agreement was pushed forward by the great powers too and it was finally signed in San Remo, it set the size of the expropriated territories to be 578,556 acres; following harsh debates the parties accepted a total of 130 million gold crowns in total as compensation. ${ }^{27}$ This is how the Redemption Conferences of The Hague started, ending with the agreements signed in Paris on 28 April 1930. Romania, Czechoslovakia and Yugoslavia did not recognize the authority of the joint tribunal lawsuits. The Agrarian Fund was established as an Italian initiative; it took over the defendant role of the Little Entente states in agrarian lawsuits. The Hungarian government was criticised for agreeing in The Hague and Paris to pay the compensation of the optants above redemption. Bethlen's personal interest was particularly emphasised. Due to the financial agreements in Paris no point was seen in further debates and soon afterwards Hungary suspended all its state redemptions, proceeding with all war debts after the Treaty of Lausanne signed on 9 July $1932 .{ }^{28}$

The Vice mayor of Baja and several other officials were sent for internment to Valjevo by government commissioner Matic because of defiance against Serbian decrees. ${ }^{29}$ Prime Minister Pál Teleki was informed about this in several letters. ${ }^{30}$

The Hungarian Royal Finance Ministry filed a complaint with István Bethlen on 25 March 1925 about the damages that the free royal city of Pécs suffered during Serbian occupation.

23 Ibidem, file 5341/1926.

24 Gábor ARADI, A San Remo-i tárgyalások magyarországi előkészítése, in: Levéltári Szemle 52, 2002 , 3, 27.

25 Ibidem, 31.

26 lbidem, 33.

27 Ibidem, 35. Szterényi's proposal for the starting date of the San Remo negotiations was 1 November 1928.

28 ARADI, 34-38.

$29 \mathrm{MNL}-\mathrm{OL}, \mathrm{K} 28, \mathrm{ME}, \mathrm{KH}, 28$. 3. article 6. file 1679/1921.

30 MNL-OL, K 28, ME, KH, 28. 3. article 6. letter of 13 April 1921 from Gusztáv Gratz. 
The complaint was not verified but an agreement was reached with the League of Nations delegation in Budapest: the fact would endure but the claim would not as long as the Czech and South Slavic states did not claim for relief. Care had to be taken that the Yugoslavian state would not submit claims for the costs of occupation, even though there were no examples of such claims for payments in the history of the Redemption Commission. ${ }^{31}$ The minister of internal affairs wrote a letter on the position of the Yugoslavian double property holders on 2 August 1933. The free royal city of Pécs' Baranya County lordlieutenant claimed that the Yugoslavians were forcing the double property holders by all possible means to sell their estates there. ${ }^{32}$

\section{Pensions, Affairs of Citizenship}

The subject of the cooperation within the framework of the former states of the AustrianHungarian Monarchy, on the agreement on pensions, deals mainly with the "Agreement on Pensions signed in Rome", accepted on 6 April 1922. In addition, it also deals with other agreements between Austria and countries like Italy, Yugoslavia, Poland, Romania and Czechoslovakia, which were not regulated by the above mentioned agreement. These latter agreements were made on 30 November 1930 and pertained to the pensioners in all districts and regions of the countries concerned. Finally, we need to mention the bilateral agreement regarding the pensions, subsidies and other allowances provided as advanced payments, signed on 3 February 1929.

The case of the military pensioners from Transylvania was interesting (72 pensioners, 70 widows, widowers and orphans), as they turned to the Hungarian government for the determination and provision of their pensions. The Prime Minister sought the help of experts in the matter and - on the grounds of Article 199 of the Treaty of Trianon, answered that Hungary could not provide an advance on the pensions however, he promised to intervene with the Romanian government in order to help solve the problem. ${ }^{33}$

At the same time, Daruváry informed the Prime Minister about the fact that Italy had invited Hungary to Rome to continue with the negotiations. ${ }^{34}$ Subsequently, after the Hungarian ministers discussed the options, it was decided not to travel to Rome, since a more favourable decision, than the convention of Rome in April 1922, could not be expected. They also feared more questions from the Italian party. ${ }^{35}$

There were negotiations between Austria and Hungary about the position of the foundations and public bodies, and there was even a pre-conference convened for the Rome Conference - which was held on 1 December 1924. The subject of mutual foundations was discussed in Rome on 14 October 1925. ${ }^{36}$

The Hungarian Council of Ministers debated the case of movable and immovable

$31 \mathrm{MNL}-\mathrm{OL}, \mathrm{K} 28, \mathrm{ME}, \mathrm{KH}, 28$. 3. 3. article 6. file 3425/1925.

$32 \mathrm{MNL}-\mathrm{OL}, \mathrm{K} 28, \mathrm{ME}, \mathrm{KH}, 28$. 3. 3. article 6. file 11853/1933.

33 MNL-OL, K28, ME, 1. csomó. 2. tétel. 5425/1923, Fol. 30-31.

$34 \mathrm{MNL}-\mathrm{OL}, \mathrm{K} 28, \mathrm{ME}$, 3. csomó 6. tétel, 4833/1924.

35 MNL-OL, K28, ME, 3. csomó 6. tétel, 4833/1924. Fol. 302.

36 MNL-OL, K28, ME, 3. csomó 6. tétel, 7347/1924. 
assets, and also adopted a position regarding the suggestion presented by the Austrian government - in connection with the movable assets, the suggestion was to distribute the assets among the countries according to a rate, while in the case of the immovable assets and the territory was the decisive factor. The country where the territory on which the asset lay became the owner of it. These principles worked in harmony with the practice of the distribution of assets and debts applied later. ${ }^{37}$

The question regarding Archduke William Habsburg also had to be answered, and in accordance with the law in force regarding his Hungarian citizenship. This case raised the question of dual citizenship, however, in agreement to the answer by the minister of justice, the Hungarian citizenship could only be granted to those who stayed within the Hungarian borders. ${ }^{38}$

\section{The Early Accounts in ,old Hungarian crown'}

As a result of the separation of currency, and the Peace Treaty, after the collapse of the Austrian-Hungarian Monarchy, the so called, old crown claim' came into existence. This was due to the private debt claim of Austrian and Hungarian citizens, in the newly formed German Austria and the territories provided to the former states of the Monarchy. In the case of Yugoslavia, Czechoslovakia, Italy and Romania, the subject of dispute was what currency and what exchange rate to apply to the number of claims, in crowns, that had accumulated over time.

The question was solved by applying the old crown agreements ${ }^{39}$ made with the former states of the Monarchy, for which either an exchange rate for the old crown debts was decided upon, or an account procedure was chosen (Czechoslovakia and Italy).

In order to solve the problematic situations after the rulings made in the case of old crown claims ${ }^{40}$ and on the grounds of the rules laid down in the old crown agreement and published within Federal Law, courts were established by the Austrian Republic and the former states of the Monarchy.

These courts were meant to deal with the international duties of Austria. They were expected to operate until all the old crown debt claims were settled and all the relevant numbers of legal cases between Austrian and foreign parties were resolved in a satisfactory manner.

The Austrian-Romanian Tribunal, in theory, ceased to operate in 1932 however, the court carried on functioning during the following years.

37 MNL-OL, K28, ME, 3. csomó 6. tétel, Fol. 350-355.

38 MNL-OL, K28, ME, 3. csomó 6. tétel, 8067/1925. Fol. 32-40.

39 Österreichisches Staatsarchiv (Austrian State Archive; hereinafter referred only as ÖStA) - Archiv der Republik Bundesministerium für Finanzen (hereinafter referred only as AdR and BMfF) Dept 17-Frieden, Faszikel 81 Jahr(e) 1931-1933. Karton 136 Schiedsgericht. Zl. 17 179/32.

40 lbid. file 17 179/32. The tribunals of the successor states solved partly issues which were settled in earlier koronas. The agreements issued in the Austrian federal corpus juris included obligations in controversial issues which were to be settled in Austrian koronas. Austria had for example the following agreements: AltkronenÜbereinkommen mit Jugoslavien, BG. BI. Nr. 116 v. J. 1924, mit Italien BG. Bl. Nr. 160. V. J. 1924, mit Rumänien BG. BI. 431 v. J. 1925, mit Tschechoslowakei BG. BI. 92 v. J. 1926. 
The code procedure of the international tribunals between the Austrian Republic and Italy - the payment of private debts and arrangement of private claims, was set according to the agreement signed on 22 April 1922. These tribunals dealt with the cases of the citizens of the Austrian Republic and Italy, and of the territories that used to belong to the old Austrian Empire. The international tribunals were established to decide which cases were valid following the agreement of 6 April 1922. These tribunals operated with the help of two senates, one of them ruling under the direction of a president chosen by the Austrian party - or its deputy - with an Austrian and an Italian judge, while the other senate did the same under the direction of a president chosen by the Italian government or their deputy, and with an Austrian and an Italian judge as well. The legislative charges and costs of these submissions were decided upon by the senate, after the negotiating parties and the representatives of the states had presented their views within a hearing closed to the public. If the tribunal granted the application, it had to be stated in which phase of the procedure there was a withdrawal. ${ }^{41}$

The Austrian-Czechoslovakian Tribunal was one of the most active organisations. Until 1932, 804 cases were referred to the court at the Senate of Vienna, out of which 760 saw rulings made. As the accounting procedure carried on, the number of cases referred to the court increased by 10-15 every month.

The Austrian Council of Ministers appointed the president of the Austrian-Italian Tribunal on 25 November 1931. Up until this time the applications had been truly involved, the assets at stake were worth millions of schillings, and, in any case, could not be provided by the Austrian government. It could not be solved through the legislation charges either, since it did not cover the sum. So, according to the law of 17 March 1926 (Federal Law Gazette, issue nr. 66), funds were used from the Office of Liquidation - established on the grounds of the debts settled by Austrian citizens, and divided among the creditors of the new Italian debtors.

The Austrian-Romanian Tribunal started to operate in March 1929 and made a judgement in some 20 cases until 1932. Then, the Austrian judge ordered the court to settle every case in process during one single hearing - if possible, with the help of the securities paid in, and taking into consideration the independent code of procedure.

We can draw the conclusion that the first two courts operated at maximum level at the beginning of the 1930s. They held more sittings, which required preparatory phases as well as the wording of verdicts and daily work by the presidents.

These courts had to operate - according to the spirit of the Peace Treaty, until all the crown statements were finished, the open cases were closed and the numerous and significant legal procedures were solved with a favourable decision for both the Austrian and the foreign parties - whether they were private individuals, or corporations. ${ }^{42}$

The, The Hague Conference and the Agreement of Prague annulled the payment duties after the First World War, however, this also meant the beginning of the operation of the Austrian-Hungarian (and other) tribunals. Finally, the Austrian-Hungarian Tribunal was set to rights following the Hague and Paris agreements, on 15 September 1930. Subsequently,

41 ÖStA - AdR - BMfF Dept 17-Frieden, Faszikel 92 Jahr(e) 1919-1927. Karton 148. Zl. 104122/26.

42 ÖStA - AdR - BMfF Dept 17-Frieden, Faszikel 81 Jahr(e) 1931-1933. Karton 136 Schiedsgericht. Zl. $17179 / 32$. 
the Kingdom of Hungary raised one main action and two auxiliary ones, while Austria opened with a counter action and thousands of pages of documents and submissions were exchanged. The subject of the Hungarian action was the joint-ownership of the court assets, museums, some items of the court library and other collections, and the assets of the External Service and the military assets. By 1938, with the help of a neutral president, both parties (Austria and Hungary) came to an agreement regarding each point of the actions, with the exception of the military assets located within the new Austrian borders. These agreements were partly signed and accepted by both countries, and partly paraph signed, up until 1938 when Hungary decided to postpone the signing and ratification of some of the agreements, and try to solve the open actions either by a court decision or an agreement.

Hungary required the value of 450 million gold crowns for the military assets that were once held in joint ownership, and to which it was entitled to according to the quote-rate division. At the beginning of 1938, the action was at the phase of the evidentiary procedure and, since it was fairly complicated, it took several more years to solve.

Before the spring of 1938, the former Hungarian Prime Minister presented an account to the Austrian chancellor in order to reach an agreement, however it did not have a satisfactory result. Austria did not make the sacrifice to place a burden on the Austrian budget and did not sign the agreement with Hungary. The tribunal set the next meeting for the case for April 1938, but the Austrian representative - taking into consideration the results of the month of March, postponed it until the arrival of the suggestions by the German government. ${ }^{43}$

\section{Abstract}

The First World War brought total economic exhaustion to the Central-European region. It caused problems in the workforce, and finances. Together with inflation, it emerged in the form of a serious government debt. The agricultural balance of the world was lost, as well as the system of financial gold standard. In this, new, Central-European region, the typical form of existence was the economy of self-supply, and the policy of seclusion. After the dissolution of the great economic unity, the national assets became the possession of the former member states of the Monarchy; however, in numerous cases it gave grounds for quarrels and complaints. Among these, in this study, I concentrated on the cases of options, pension provisions and old crown accounts.

\section{Keywords}

government asset, war loan, inflation, disintegration, expropriation, option, joint tribunal, economic self-sufficiency, Treaty of Trianon, Kingdom of Hungary, Austrian Republic 


\section{References}

Magyar Nemzeti Levéltár Országos Levéltára (MNL-OL)

The State Archives of the Hungarian National Archives

A miniszterlnökség iratai (Prime Minister documents) - Kisebbségügyi hivatal (Department of Minorities)

Österreichisches Staatsarchiv (ÖStA)

Archiv der Republik - Bundesministerium für Finanzen (AdR - BMF)

Austrian State Archive

Archive of the Republic - Federal Ministry of Finance

Departement Frieden/17 (1918 - 1940)

ARADI, Gábor: A San Remo-i tárgyalások magyarországi előkészítése, in: Levéltári Szemle 52, 2002, 3, 24-38.

BEREND, Iván T. - RÁNKI, György: Ungarns wirtschaftliche Entwicklung 1849-1919, in: Die Habsburgermonarchie 1848-1918, Adam WANDRUSZKA - Peter URBANITSCH (eds.), Band I. Die wirtschaftliche Entwicklung, Alois BRUSATTI (ed.), Wien 1973, 520-527. BROADBERRY, Stephen - HARRISON, Mark (eds.): The Economics of World War I, Cambridge 2005.

Corpus Juris Hungarici, Budapest 1922, 294-295.

GRATZ, Gustav - SCHÜLLER, Richard: Der wirtschaftliche Zusammenbruch ÖsterreichUngarns. Die Tragödie der Erschöpfung, Wien 1930.

HASELSTEINER, Horst - SZÁVAI, Ferenc (eds.): Dokumente des österreichisch-ungarischen Schiedsgerichtes in Lausanne (1930-1938), Frankfurt/M., Berlin, Bern, Bruxelles, New York, Oxford, Wien 2001.

MARBURG, Ernst: Der rumänisch-ungarische Optantenstreit vor dem Gemischten Schiedsgericht und dem Völkerbund. Zugleich ein Beitrag zur Lehre von der Enteignung im Völkerrecht, in: Frankfurter Abhandlungen zum Kriegsverhütungsrecht. Heft 8, Friedrich GIESE - Karl STRUPP (eds.), Leipzig, 1928.

SZÁSZY, István: Az államok közötti utódlás elmélete, Budapest 1928.

SZTERÉNYI, József Báró - LADÁNYI, Jenő: A magyar ipar a világháborúban, Budapest 1934. 